\title{
Cash Concentration and Liquidity Policy
}

\author{
Magdaléna Kubranová ${ }^{*}$ \\ ${ }^{1}$ University of Economics in Bratislava, Faculty of Business Management, Department of Business \\ Finance, Dolnozemská cesta 1/b, 85235 Bratislava, Slovakia
}

\begin{abstract}
The purpose of this article is to present how to create an effective payment and collection policy in the corporation. The paper shows defining characteristics and analyses of chosen aspects of corporate payment and collection policy which are the important field in corporate liquidity policy. The rules on payment terms are one of the key factors which are controlled in most contracts involved in businesses. A key treasury task is to collect and concentrate incoming cash as quickly as possible, so that it is made available for operational and investment purposes. The methods used in the solving the problem include analysing the current solution in liquidity policy when many organizations have a large number of highly dispersed locations that collect or disburse cash. This article uses a combination of qualitative and deductive methods. A comprehensive analysis of liquidity policy is also related to cover the details of how to create such a forecast, the reliability of the source information used within it, and how to improve the document about liquidity policy on an ongoing basis.
\end{abstract}

\section{Introduction}

Liquidity policy should be an organized, repeatable practice or philosophy that a corporate adopts in order to control the risk it assumes when extending net payment terms to its customers. It can be as general or as specific as corporate would like it to be.

First and for a most corporate should have a credit policy in order to protect its accounts receivable. The corporate probably go to great pains to conceive design, manufacture, warehouse, market, sell and ship great product. Obviously, these are essential to businesses success. Credit policy which is included payment and collection policy will give stability, efficiency and effectiveness to company. A solid, repeatable policy allows all departments to understand company's values and work flows. Without it, there is no set way of doing things that pertain to cash flow. It also prevents any misunderstandings between the sales and credit departments which can sometimes cause unnecessary friction. Another benefit to having a set policy is that it will provide consistent customer care. By knowing how accounts will be cleared for credit and the manner in which collections will be conducted, customers will know exactly what to expect when dealing with company. The better company's focused is that customers will understand and follow requirements.

* Corresponding author: magdalena.kubranova@euba.sk 
Payment and collection policy should be a central function of any corporate. Good collection policy balances conflicting goals. The company wants cordial relations with its customers. It also wants them to pay their bills on time. [1, 7] Cash must be made available in the correct amounts and with the proper timing to ensure that company functions are not impeded. It is impossible to manage effectively without an accurate cash forecast that is completely reliable.

\section{Presentation of surveyed results}

The type of payment method that a company uses to pay its suppliers employees has a considerable bearing on the timing of when cash departs a company's bank accounts, which in turn impacts the cash planning of the treasury department. The current account will handle all the business's receipt and payments so every transaction will pass through this account at some stage. In structuring transaction services there are several aspects to consider.

\subsection{Payment transaction services}

There are some types of transaction that are likely to pass through the current account: physical cash (deposits and withdrawals); paper (lodgements and cheques, this type of transaction is diminishing as means of settlement); electronic (receipts and payments) the most common way for business to transact with another; card (credit and debit card receipt and payments) the most common way for a business to transact with a individual consumer; foreign (exchanges to or from business's trading currency).

The cost of running a current account normally consists of monthly account maintenance charge and transaction chargers that depend on type, with electronic transactions being cheaper than others.

In a world of sophisticated fraud, businesses need strict internal controls over account access, payment originations, authorisations, validations and reviews. [2,10] These internal controls need to be operated in conjunction with bank to ensure there is rigorous application.

\subsection{Subsidiary liquidity management}

After accounting for all outflow and inflow payments, the subsidiary will find itself with either excess or deficient cash. It uses liquidity management to either invest its excess cash or borrow to cover its cash deficiencies. If it anticipates a cash deficiency, short-term financing is necessary. If it anticipates excess cash, it must determine how the excess cash should be used. Investing in foreign currencies can sometimes be attractive, but exchange rate risk makes the effective yield uncertain.

Liquidity management is a crucial component of a subsidiary's working capital management. [6, 7, 9] Subsidiaries commonly have access to numerous lines of credit and overdraft facilities in various currencies. Therefore, they may maintain adequate liquidity without substantial cash balances. While liquidity is important for the overall multinational corporation, it cannot be properly measured by liquidity ratios. Potential access to funds is more relevant than cash on hand.

\subsection{Centralized cash management}


The management of working capital such as inventory, accounts receivable and payable debtors and creditors and cash has a direct influence on the amount and timing of cash flows. Working capital management and the management of cash flow are integrated. We discuss these elements before focusing on cash management.

Each subsidiary should manage its working capital by simultaneously considering all of the points discussed thus far. Often, though, each subsidiary is more concerned with its own operations than with the overall operations of the multinational corporation. Thus, a centralized cash management group may need to monitor, and possibly manage, the parent-subsidiary and inter subsidiary cash flows. This role is critical since it can often benefit individual subsidiaries in need of funds or overly exposed to exchange rate risk. [3]

While each subsidiary is managing its working capital, there is a need to monitor and manage the cash flows between the parent and the subsidiaries, as well as between the individual subsidiaries. This task of international cash management should be delegated to a centralized cash management group. International cash management can be segmented into two functions: optimizing cash flow movements and investing excess cash.

The centralized cash management division of an MNC cannot always accurately forecast events that affect parent-subsidiary or inter subsidiary cash flows. It should, however, be ready to react to any event by considering: any potential adverse impact on cash flows, and how to avoid such an adverse impact. $[3,8,10]$ If the cash flow situation between the parent and subsidiaries result in a cash squeeze on the parent, it should have sources of funds (credit lines) available. On the other hand, if it has excess cash after considering all outflow payments, it must consider where to invest funds. This decision is thoroughly examined shortly.

\subsection{Techniques to optimize cash flows}

Cash inflows can be optimized by the following techniques: accelerating cash inflows; minimizing currency conversion costs; managing blocked funds; managing inter subsidiary cash transfers. The first goal in international cash management is to accelerate cash inflows, since the more quickly the inflows are received, the more quickly they can be invested or used for other purposes. Several managerial practices are advocated for this endeavour, some of which may be implemented by the individual subsidiaries. First, a corporation may establish lockboxes around the world, which are post office boxes to which customers are instructed to send payment. When set up in appropriate locations, lockboxes can help reduce mailing time (mail float). A bank usually process incoming checks at a lockbox on a daily basis. [4, 5] Second cash inflows can be accelerated by using preauthorized payments, which allow a corporation to charge a customer's bank account up to some limit. Both preauthorized payments and lockboxes are also used in a domestic setting. Because international transactions may have a relatively long mailing time, these methods of accelerating cash inflows can be quite valuable for multinational corporations.

Minimizing currency conversion costs. Another technique for optimizing cash flow movements, netting, can be implemented which the joint effort of subsidiaries or by the centralized cash management group. The technique optimizes cash flows by reducing the administrative and transaction costs that result from currency conversion. Over time, netting has become increasingly popular because it offers several key benefits. First, it reduces the number of cross-border transactions between subsidiaries, thereby reducing the overall administrative cost of such cash transfers. Second, it reduces the need for foreign exchange conversion since transactions occur less frequently, thereby reducing the transaction costs associated with foreign exchange conversion. Third, the netting process imposes tight control over information on transactions between subsidiaries. Thus, all subsidiaries engage in a more coordinated effort to accurately report and settle their various 
accounts. Finally, cash flow forecasting is easier since only net cash transfers are made at the end of each period, rather than individual cash transfers throughout the period. Improved cash flow forecasting can enhance financing and investment decisions.

A bilateral netting system involves transactions between two units: between the parent and a subsidiary, or between two subsidiaries. A multilateral netting system usually involves a more complex interchange among the parent and several subsidiaries. For most large multinational corporations, a multinational netting system would be necessary to effectively reduce administrative and currency conversion costs. Such a system is normally centralized so that all necessary information consolidated. From the consolidated cash flow information, net cash flow positions for each pair of units (subsidiaries, or whatever) are determined, and the actual reconciliation at the end of each period can be dictated. The centralized group may even maintain inventories of various currencies so that currency conversions for the end-of-period net payments can be completed with-out significant transaction costs. Multinational corporations commonly monitor the cash flows between their subsidiaries with the use of inter subsidiary payments matrix.

Managing blocked funds. Cash flows can also be affected by the host government's blockage of funds, which might occur if the government requires all funds to remain within the country in order to create jobs and reduce unemployment. To deal with funds blockage, the multinational corporation may implement the same strategies used when a host country government imposes high taxes. To make efficient use of these funds, the multinational corporation may instruct the subsidiary to set up a research and development division, which incurs costs and possibly generates revenues for other subsidiaries.

Another strategy is to use transfer pricing in a manner that will increase the expenses incurred by the subsidiary. A host country government is likely to be more lenient on funds sent to cover expenses than on earnings remitted to the parent. Most tax treaties require that transfer pricing be conducted at market rates. There for a policy of artificially inflated transfer prices resulting in subsidiaries in developing countries paying very high prices for services or goods from head office is of dubious legality and ethics.

When subsidiaries are restricted from transferring funds to the parent, the parent may instruct the subsidiary to obtain financing from a local bank rather than from the parent. By borrowing through a local intermediary, the subsidiary is assured that its earnings can be distributed to pay off previous financing. Overall, most methods of managing blocked funds are intended to make efficient use of the funds by using them to cover expenses that are transferred to that country.

Managing inter subsidiary cash transfers. Proper management of cash flows can also be beneficial to a subsidiary in need of funds. The leading or lagging strategy can make efficient use of cash and thereby reduce debt. Some host governments prohibit the practice by requiring that a payment between subsidiaries occur at the time the goods are transferred. Thus, multinational corporations need to be aware of any laws that restrict the use of this strategy.

\subsection{Complications in optimizing cash flow}

In some cases, optimizing cash flow can become complicated due to characteristics of the multiplication corporation. If one of the subsidiaries delays payments to other subsidiaries for supplies received, the other subsidiaries may be forced to borrow until the payments arrive. A centralized approach that monitors all subsidiary payments should be able to minimize such problems.

The existence of government restrictions can disrupt a cash flow optimization policy. Some governments prohibit the use of a netting system, as noted earlier. In additions, some countries periodically prevent cash from leaving the country, thereby 
preventing net payments from being made. These problems can arise even for multinational corporations that do not experience any company-related problems.

The abilities of banks to facilitate cash transfers for multinational corporations vary among countries. Banks in the developed world are advanced in the field, but banks in some other countries do not offer services. Multinational corporations prefer some form of zero-balance account, where excess funds can be used to make payments but earn interest until they are used. In addition, a bank may not update the multinational corporation bank account information sufficiently or provide a detailed breakdown of fees for banking services. Without full use of banking resources and information, the effectiveness of international cash management is limited. In addition, multinational corporations with subsidiaries in, say, eight different countries will typically be dealing with eight different banking systems. Much progress has been made in foreign banking systems in recent years. As time passes and a more uniform global banking system emerges, such problems may be alleviated.

\subsection{Centralized liquidity policy}

The multiplication corporation short-term investing policy can either maintain separate investments for all subsidiaries or employ a centralized approach. Recall that the function of optimizing cash flows can be improved by a centralized approach, since all subsidiary cash positions can be monitored simultaneously. With regard to the investing function, centralization allows for more efficient usage of funds and possibly higher returns. Here the term centralized means that excess cash from each subsidiary is pooled until it is needed by a particular subsidiary.

Centralization when subsidiaries use the same currency. To understand the advantages of a centralized system, consider that the rates paid on short-term investments such as bank deposits are often higher for larger amounts. Thus, if two subsidiaries have excess cash of $50000 €$ each for one month, the rates on their individual bank deposits may be lower than the rate they could obtain if they pooled their funds into a single $100000 €$ bank deposit. In this manner, the centralized - pooling approach generates a higher rate of return on excess cash. The centralized approach can also facilitate the transfer of funds from subsidiaries with excess funds to those that need funds.

Centralized cash management of multiple currencies. Centralized cash management is more complicated when the multiplication corporation uses multiple currencies. All excess funds could be pooled and converted to a single currency for investment purposes. However, the advantage of pooling may be offset by the transaction costs incurred when converting to a single currency. Centralized cash management can still be valuable, though. The short-term cash available among subsidiaries can be pooled together so that there is a separate pool for each currency. Then excess cash in particular currency can still be used to satisfy other subsidiary deficiencies in that currency. In this way, funds can be transferred from one subsidiary to another without incurring transaction costs that banks charge for exchanging currencies. This strategy is especially feasible when all subsidiary funds are deposited in brunches of a single bank so that the funds can easily be transferred among subsidiaries.

Another possible function of centralized cash management is to invest funds in securities denominated in the foreign currencies that will be needed by the subsidiaries in the future. [8] Multinational corporations can use excess cash to invest cash in international money market instruments so that they can cover any payables positions in specific foreign currencies. If they have payables in foreign currencies that are expected to appreciate, they can cover such positions by creating short-term deposits in those currencies. The maturity of a deposit would ideally coincide with the date at which the funds are needed. 
Impact of technology on centralized cash management. International cash management requires timely information across subsidiaries regarding each subsidiary's cash positions in each currency, along with interest rate information about each currency. A centralized cash management system needs a continual flow of information about currency positions so that it can determine whether one subsidiary's shortage of cash can be covered by another subsidiary's excess cash in that currency. Given the major improvements in online technology in recent years, all multinational corporations can easily and efficiently create a multinational communications network among their subsidiaries to ensure that information about cash positions in continually updated.

The electronic communications network may be more sophisticated than the one described here, but this description illustrates how easy it is for an multinational corporation parent to continuously monitor the cash balances of each subsidiary and communicate instructions among subsidiaries. The process of transferring funds among subsidiaries may be especially easy when all the multinational corporation's subsidiaries use branches of the same bank. [11, 12] A communications network allows the multinational corporation to make the best use of each subsidiary cash, which reduce the amount of external financing needed and reduce the multinational corporation's exchange rate risk.

\section{Discussion}

There are several cash aggregation services available from banks that can assist in this process. One approach, called cash sweeping, moves cash into a central concentration account; this is useful for centralized payment and investment systems. An alternative, notional pooling, aggregates cash from multiple accounts for investment purpose, without actually shifting the cash into a concentration account. Banks offer a wide range of liquidity management and optimisation services. Cash pooling is a product designed for corporation operating in interrelated groups. Main advantages are that all members of the group, whether large or small, get better interest rates, whether for deposits or loans, based on the overall position of the group; centralisation of balances and more efficient management of group's cash flows and more efficient use of group's own resources. Fund sharing within the group gives the corporate opportunity to decrease the cost of external resources.

Local effective cash pooling is efficient use of liquidity of the accounts in cash pooling and option of common drawdown of a credit line by all cash pooling members. Physical concentration of funds on a master account with or without return to individual accounts of the system and money flows which need to be posted really take place between the accounts included in the system in order to determine the consolidated status. There is option to make an individualised setting of balances, limits, and sharing of funds at individual Cash Pooling levels as required by the client and next option to calculate and keep records about the loans within the group along with the information concerning the interest rates applicable to these intra-group loans.

Fictitious cash pooling firms will have better interest rate resulting out of the consolidated balance of the group. No transactions take place between individual accounts of the system in order to ascertain the consolidated balance. Benefits resulting from inclusion of the account into the system are allocated to the master account or directly to individual accounts of the system. Firm does not have to post loans within the group since there is no real money flow.

Cross border cash pooling implementation may be connected with the implementation of the Real Cash Pooling. Automated transfers of balances at the end of each banking day between accounts of the firms kept in various banks of the bank group. There is option to set the transfer details (credit, debit, both credit and debit) and option to set the permitted 
daily debit balance on the subordinated account and its automated settlement at the end of each banking day from the master account kept in another bank of the bank group.

\section{Conclusion}

Irrespective of the type of cash concentration system being used, the treasury manager should periodically review a number of structural issues involving a company's use of bank accounts. These issues are examined low-usage accounts, review the accounts of acquired businesses, mandate deposit cut off times and administration charges. The ongoing concentration of accounts has an additional benefit, which is that the smaller number $o$ remaining banks will see that more cash is being stored in their accounts. The need for a cash concentration system depends upon the structure of business.

\section{References}

1. S. M. Bragg, Corporate Cash Management. A Treasurer's Guide. Published by Accounting Tools, Inc., Centennial, Colorado. 245 p. (2014)

2. E.F. Brigham, P.R. Daves, Intermediate financial management. Mason: Thomson / South-Western Academic Resource Center USA,. 1040 p. (2007)

3. Ch. W. L. Hill. International business : competing in the global marketplace. New York : McGraw-Hill/Irwin, 738 s. (2009)

4. A. Penning, M. Fardon, Cash management. Published by Osborne Books Limited, Worcester. 2010. 190 p. (2010)

5. J. Tennent, Guide to cash management. How to avoid a business credit crunch. London: The economist in association with Profile Books Ltd. p. 211. (2012)

6. J. Kotlebová, Changes in the Holding of Liquidity during the Present Financial Crisis. In European Financial Systems 2014. International Scientific Conference. Masaryk University, 2014. pp. 322-329. http://is.muni.cz/do/econ/sborniky/2014/proceedingsEFS-2014.pdf (2014)

7. K. Belanová, Financial market imperfections and corporate investments. -. In Challenges for financial sector of CEE countries in overcoming problems of economic integration in the EU. International conference on currency, banking and international finance. Bratislava, Slovak Republic. pp. 17-23 (2017)

8. K. Belanová, The Impact of financial market imperfections on the investment - cash flow sensitivity in Slovak companies. International scientific conference. European financial systems 2017. proceedings of the 14th international scientific conference : Czech Republic. - Brno : Masaryk University. pp. 16-19 online (2017)

9. R. Pakšiová, The Critical analysis of profit for its allocation decision-making. Scientific Annals of Economics and Business. Alexandru Ioan Cuza University of Iasi, vol. 64, no. Special Issue, pp. 41-56 online.(2017)

10. R. Pakšiová, Z. Kubaščíková, Business property of company and investments. Procedia economics and finance : 16th Annual conference on finance and Accounting, Prague, vol. 25, pp. 70-78 online (2015)

11. Ł. Kurowski, P. Smaga, Monetary Policy and Cyclical Systemic Risk - Friends or Foes? Prague Economic Papers: $<A>$ Bimonthly Journal Of Economic Theory And Policy 27, 5, 522-540 (2018) 
12. A. Belke, J. Klose, Forecasting ECB Policy Rates with Different Monetary Policy Rules. Finance A Úvěr: Czech Journal Of Economics And Finance, 69, 3 .238-252 (2019) 